\title{
Column Leaching of Fine Coal Tailings: Impact on Environment and Thickener Operation
}

\author{
Dumisane Moyakhe ${ }^{1 *}$, Elvis Fosso-Kankeu ${ }^{1}$ and Quentin Campbell ${ }^{1}$
}

\begin{abstract}
- the coal mining sector is synonymous with generating large quantities of waste. A comprehensive fraction of the waste is classified as fines $(-500 \mu \mathrm{m})$ and ultrafine $(-100 \mu \mathrm{m})$ particles, which accounts eleven per cent of the run-of-mine coal mined in South Africa reported by England et al. These fines are transported to tailings dumps in slurry form as discard. Consumption of water is thus significant in the fines handling. Due to environmental restrictions, most of the water used is recovered - aided by thickeners and filters - and recirculated during beneficiation. The contact time between fine coal and water influences the quality of the recycled water. It is hypothesized that leaching occurs during fine coal tailings slurry handling. Effectively changing the water chemistry to some degree, leading to operational and environmental difficulties. The study focuses on predicting the impact of leaching on the mobilization and speciation of heavy metals and light metals which would possibly contaminate the environment. In addition, investigate the financial and operational impact the change in water properties may pose in the thickening process. Witbank seam 4 tailings were samples were obtained and a twelve-week column leaching experiment conducted. Chemical and mineral composition of the solid tailings were determined by means of $X$-ray fluorescence (XRF) and X-ray diffraction (XRD) respectively. The XRD specified quartz as the main mineral present. Other minerals were kaolinite, anatase, troilite, and magnetite. Metal analysis was conducted leachate using an inductively coupled plasma optical emission spectroscopy (ICP-OES). PHREEQC was used to model the metal speciation results. Furthermore, batch-settling experiments were conducted using the altered water quality to determine sedimentation properties. The results showed that the leaching phenomenon has a negative impact on the environment and the thickener operation
\end{abstract}

Keywords - Fine coal, tailings, leaching, settling, heavy metals, speciation.

\footnotetext{
1 Dumisane Moyakhe, Water Pollution Monitoring and Remediation Initiatives Research Group in the CoE C-based fuels School of Chemical and Minerals Engineering, Faculty of Engineering, North-West University, Potchefstroom - South Africa
}

\section{INTRODUCTION}

Globally, the mining industry is understood to have water extensive processes. The narrative is no different for coal beneficiation, where water is mainly used as process water and a transport medium in fine tailings handling in waste management. Characteristically, high volumes of water are required to handle large quantities of fine coal tailings generated during production. In consequence of strict water restrictions, most of the water is then separated from the waste tailings, recovered and recycled back into the processes [1]. Typically, in a slurry form, the waste tailings are then impounded in tailings dams [2,3]. This paper focuses on two major challenges imposed on these processes. Firstly, coal tailings, particle size below $150 \mu \mathrm{m}$, contains solids such as clays, shale, silts, sand and coal particles [3]. Due to the increased surface area and contact time between the process water and tailings, metals from these solids dissolve into the water and changes the chemistry, mainly $\mathrm{pH}$, conductivity and hardness, of the water over time [4]. The change in water chemistry combined with the complex nature of fine coal tailings is the principal cause of technical and financial challenges facing fine coal dewatering. The addition of polymers, as it is common practice, to assist in accelerating the dewatering, introduces more challenges to an already complex problem [5]. Lastly, since the coal fines are impounded in large tailings dams, there exists a high potential for Acid Mine Drainage (AMD) formation[6]. This is due to the weathering and oxidation of pyrite $\left(\mathrm{FeS}_{2}\right)$ that is inherent to the coal mineral matrix structure[7]. The formation of AMD impacts the environment negatively, lowering the $\mathrm{pH}$ of the water and inducing speciation of heavy metals into the environment[8]. The process starts when pyrite is oxidized producing sulfuric acid ferrous sulfate. The sulfuric acid that forms permeates through the tailings dissolving metals. The solubility of the heavy metals increases with the acidic condition during this process. The solution percolates through reaching the bottom of the tailings dam and it seeping into local ground water[9]. Thus, pollution the local water and the surrounding environment. The extent of metal displacement is dependent on the characteristics of the tailings as well as heavily influenced by the rainfall of the surrounding area. This implies that the impact of pollution is site-specific, thus it is essential to predict the potential of toxicity to the environment and implement strategies. With the increasing global carbon emission and the increasing acidity of the oceans, it is important to investigate 
the impact of acid rain on the current tailings dams as the impact may be different from that of normal rainfall $[9,10]$. The paper is focused on how the leaching influence the water chemistry and settling properties of tailings during thickener operation, as well as the degree speciation of heavy metals and potential environmental impact of leaching and acid rain.

\section{EXPERIMENTAL SETUP AND METHODOLOGY}

\section{A. Materials}

Fine coal tailings from a Witbank Seam 4 coal were used for this study and were collected from a coal beneficiating plant in Mpumalanga, South Africa. The coal tailings were in a form of a filter cake, were stored in a tight seal container. Furthermore, raw water samples $(\mathrm{RW})$ and process water samples (PW) were also collected. A Non-Ionic flocculant used for thickener operation was also sampled.

\section{B. Mine tailings characterization}

Chemical and mineral composition of the solid tailings were determined by means of X-ray fluorescence (XRF) and X-ray diffraction (XRD) respectively. The particle size distribution was also determined using Malvern Master-sizer equipment.

\section{Batch settling tests}

The flocculation experiments were carried out using the cylinder inversion batch settling jar tests. For each test, 1000 $\mathrm{ml}$ of the original slurry with a solid concentration of $5 \%$ was transferred in a glass cylinder. Various desired solution $\mathrm{pH}$ and flocculant dosages where investigated. The cylinder was inverted to disperse and mix the flocculant-slurry solution. The interface between the supernatant liquid and height of slurry the slurry as a function of time was recorded. From the recorded height versus time graph, the settling rate of the flocculated suspension is calculated. At time 15 minutes, the supernatant water was sampled to measure the turbidity of the supernatant liquid.

\section{Synthetic acid rain production}

The synthetic acid rain was prepared by means of mixing $98 \%$ sulfuric acid $\left(\mathrm{H}_{2} \mathrm{SO}_{4}\right)$ and $55 \%$ nitric acid $\left(\mathrm{HNO}_{3}\right)$. The $\mathrm{H}_{2} \mathrm{SO}_{4}$ and $\mathrm{HNO}_{3}$ were mixed at a 3:2 $\mathrm{mL}$ ratio. A fractional amount of the solution was then diluted with $100 \mathrm{ml}$ distilled water producing a buffer solution. Lastly, to produce synthetic acid rain $4 \mathrm{ml}$ of the acid buffer solution was mixed with 500 $\mathrm{ml}$ of distilled water until the reading on the Hanna Instruments $8424 \mathrm{pH}$ meter a value of 4.2. The process was repeated until a total of $8 \mathrm{~L}$ synthetic acid rain was produce.

\section{E. Column leaching experiments}

The change of physiochemical properties investigation of the coal tailings was conducted over a 12 week leaching period. The experiment was conducted in triplicates for the 3 water samples in question, the raw water sample (RW), synthetic acid rain sample (SW) and distilled water sample (DW), which served as a control sample. The columns were packed with 800 -gram coal tailings mixed with $300 \mathrm{~mL}$ of the various water samples. Each column was topped up to $10 \mathrm{~cm}$ above the packed sediment. The leachate was then sampled periodically and analyzed. The leachate $\mathrm{pH}$, temperature, oxidation-reduction potential (ORP) and the electrical conductivity (EC) were analyzed weekly, whereas the chloride ion concentration, acidity, sulfate concentration and metal analysis were determined monthly. The $\mathrm{pH}$, temperature and ORP were measured using an analytical electrode $\mathrm{HI} 8424 \mathrm{pH}$ meter - Hanna Instruments Inc. The solution conductivity was measured using a Lovibond Sensodirect 150 meter. The HI 83099 COD and Multi-parameter Photometer (Hanna Instruments Inc.) was used to measure sulfate ion concentrations. Post analysis, the leachate was returned back into the respective column.

\section{F. Titrations}

To determine the chloride ion concentrations, titrations experiments were carried out using a $0.02 \mathrm{M}$ silver nitrate $\left(\mathrm{AgNO}_{3}\right)$ solution. Potassium chromate $\left(\mathrm{K}_{2} \mathrm{CrO}_{4}\right)$ was used as an indicator. Alkalinity could not be tested as the solution was acidic. To determine the acidity of the leachates, titration with $0.02 \mathrm{M}$ sodium hydroxide $(\mathrm{NaOH})$ was conducted.

\section{G. Metal analyses}

For the metal analyses, leachate from each column was periodical. From the collected leachate, $1 \mathrm{ml}$ of each sample was diluted by a factor of 20 using distilled water and then stored in the lab fridge at $4{ }^{0} \mathrm{C}$. Inductively coupled plasma-optical emission spectrometry (ICP-OES) was then used to conduct the metal analysis.

\section{H. Speciation modelling}

The speciation of the principal metals existing within the leachates was determined using the AQUACHEM software with PHREEQC (version 3.4.0-12927) modelling software. For the basis of the study, the database Minteq.v4.dat was used. According to Striggov (2013) advancing to the use of input data, the Oxidation-Reduction Potential (ORP) had to be computed by adjusting with a correction factor attained from Field Measurements of Oxidation-Reduction Potential [8]. The value was then utilized to calculate the value of pe using equation 1:

$$
\mathrm{pe}=\mathrm{Eh} /(0.059)
$$

Where,

- pe denotes the negative logarithm of the electron activity

- Eh denotes the oxidation redox potential of the sample

The subsequent input data was then utilized for speciation computation: $\mathrm{pH}$, Eh (pe), temperature and analyzed metal concentrations, $\mathrm{Cl}^{-}$and $\mathrm{SO}_{4}$.

\section{RESULTS AND DISCUSSION}

\section{A. Particle size distribution}

The particle size distribution of the tailings is shown in Fig. 1. It is shown that the size range is between $0.8 \mu \mathrm{m}-250 \mu \mathrm{m}$. 
According to Wentworth classification, the clay sizes $(<4 \mu \mathrm{m})$ account for $18 \%$ t of the sample, silts sizes $(4-63 \mu \mathrm{m})$ account for $60 \%$ and sand sizes are $22 \underline{\%}$ (> $63 \mu \mathrm{m})$. The sand particles are made up of larger quartz and coal particles, and other silicate minerals [11]. The large surface area of fine particles increases the probability of exposure to acid mine drainage effects. Thus, metals are expected to leach in higher concentration [12].

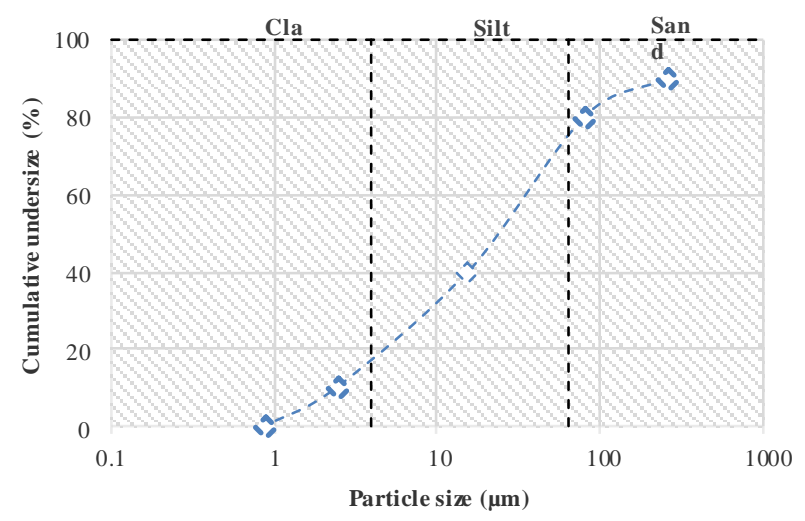

Fig. 1: Particle size distribution of coal tailings.

\section{B. Mineralogical composition}

The XRF analysis illustrated in Fig. 2, showed that the chemical composition of the tailings is primarily made up by the oxide $\mathrm{SiO}_{2}$ Additional oxides present in the tailings were $\mathrm{Al}_{2} \mathrm{O}_{3}, \mathrm{Fe}_{2} \mathrm{O}_{3}, \mathrm{SO}_{3}$ and $\mathrm{TiO}_{2}$. Furthermore, low concentration of oxides $\mathrm{CaO}, \mathrm{MgO}$ and $\mathrm{Na}_{2} \mathrm{O}$ was shown by the analysis, results consistent with typical Witbank seam 4 coal tailings sediments [13]. The mineral composition results obtained from XRD analysis are given in Table I. The analysis shows the dominating minerals to be Kaolinite and Quartz with percentage concentrations of 44.8 and $41.7 \%$ respectively. Followed by Anatase and Pyrite, 7.8 and $3.9 \%$ respectively.

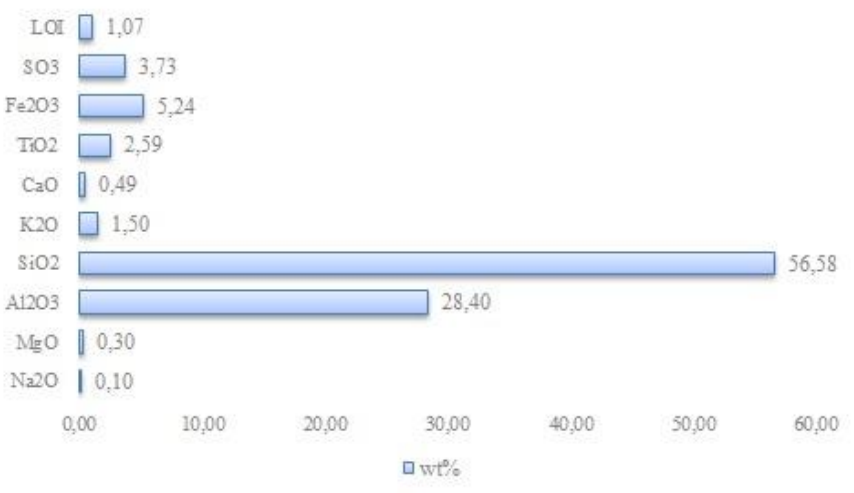

Fig. 2: XRF results of the coal tailings

Concluded by Iron (II) Sulfate and Magnetite, 0.87 and 0.86 $\%$ respectively. Depicted in Table II, is the results for metal analysis for the raw water sample (RW) and process water sample (PW) that has been recovered and recirculated in the plant. The results showed an all the metals concentration analyzed have a higher concentration on the PW sample as compared to the RW sample, which means there was a transference of trace metals from coal tailings to the water while there was contact.

TABLE I: XRD RESULTS OF COAL TAILINGS, PROPERTIES OF THE PROCESS AND RAW WATER FROM THE PLANT.

$\begin{array}{ll}\text { Process water }(\mathbf{P W}) & \\ \mathrm{pH} & 3.80 \\ \text { Conductivity }(\mathrm{mS}) & 3.10 \\ \mathrm{Mg}^{2+} \text { concentration }(\mathrm{mg} / \mathrm{L}) & 200.43 \\ \mathrm{Ca}^{2+} \text { concentration }(\mathrm{mg} / \mathrm{L}) & 561.01\end{array}$

XRD Coal tailings

Main components Quartz, Kaolinite, Anatase

Pyrite, Magnetite and Iron(II)Sulfate

$\begin{array}{ll}\text { Raw water }(\mathbf{R W}) & \\ \mathrm{pH} & 7.05 \\ \text { Conductivity (mS) } & 2.01 \\ \mathrm{Mg}^{2+} \text { concentration (mg/L) } & 170.05 \\ \mathrm{Ca}^{2+} \text { concentration (mg/L) } & 392.02\end{array}$

\section{Column leaching results}

Illustrated in Fig. 3, are the results for the column leaching of the coal tailings over a 12 week period. Depicted in Fig. 3(a) change of $\mathrm{pH}$ is shown, and from Fig. 3(b) the change in leachate conductivity is demonstrated. The experiments were conducted in triplicate samples and the average values used to construct Fig. 3 as the standard deviation for the results fell within the $10 \%$ allowable margin. The 3 samples shown are as follows:

- Control samples, sediments treated with distilled water - DW.

- Sediments treated with raw water collected from the plant - RW.

- Sediment samples treated with synthetic rain $-\mathrm{SW}$. TABLE II: METAL ANALYSIS FOR THE RAW WATER AND PROCESS WATER FROM THE PLANT

\begin{tabular}{ccccccccc|}
\multicolumn{7}{c}{ Concentration (ppm) } \\
\hline $\mathrm{S}$ & $\mathrm{Al}$ & $\mathrm{As}$ & $\mathrm{Ca}$ & $\mathrm{Cd}$ & $\mathrm{Co}$ & $\mathrm{Cr}$ & $\mathrm{Cu}$ & $\mathrm{Fe}$ \\
\hline 681.61 & 0.08 & 2.23 & 392.02 & 0.02 & 0.08 & 0.03 & 0.03 & 0.00 \\
1272 & 81.14 & 4.04 & 561.01 & 0.09 & 2.11 & 0.02 & 0.43 & 5.74 \\
\hline \hline $\mathrm{Mg}$ & $\mathrm{Mn}$ & $\mathrm{Mo}$ & $\mathrm{Ni}$ & $\mathrm{Pb}$ & $\mathrm{Sb}$ & $\mathrm{Sr}$ & $\mathrm{V}$ & $\mathrm{Zn}$ \\
\hline 170.05 & 0.00 & 0.18 & 0.00 & 0.25 & 0.29 & 1.21 & 0.03 & 0.07 \\
200.43 & 12.37 & 0.09 & 2.39 & 0.46 & 0.59 & 2.69 & 0.05 & 5.27 \\
\hline \hline
\end{tabular}

From week 1 - 8, shown in Fig. 3(a) a steady decrease in $\mathrm{pH}$ to a value between 2.5 and 2.7, between week 6 and 7 for all samples. This can be attributed to the leaching and oxidation of the pyrite mineral that is present in the sediment, thus forming acid-forming conditions [14-25]. The leachate sulfate concentration was also noticed to increase with time for all the sample, with the most increase in the distilled and raw water samples. Furthermore, due to the high concentration of $\mathrm{Ca}^{2+}$ and $\mathrm{Mg}^{2+}$ ions in $\mathrm{RW}$, refer to Table $\mathrm{I}$, the $\mathrm{pH}$ decrease is slower when compared with DW sample between week 1 and 2 , suggesting the carbonates initially act as a buffer to the 

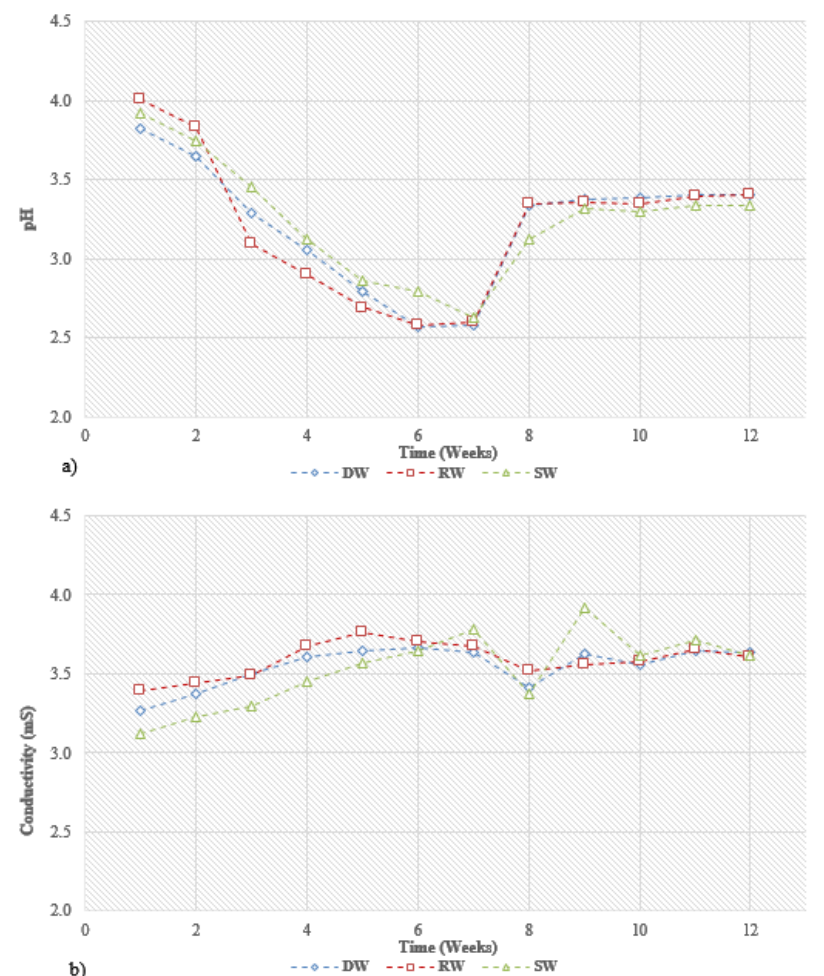

Fig. 3: Column leaching results. a) Change in $\mathrm{pH}$ level. b) Change in conductivity

forming acid [13]. This acid formation continues as the concentration of the sulfate-containing minerals is high that carbonate containing minerals, this is illustrated in Fig. 2.

However, it can also be seen that for all samples, the $\mathrm{pH}$ is lower for the samples being leached with water than with the synthetic acid rain. A similar observation is shown in Fig. 3(b) for the conductivity results. The conductivity increases with a decreasing $\mathrm{pH}$. Resulting from not necessarily the lowering of the solution $\mathrm{pH}$, but the increasing concentration of anions and cations dissolved in the solution. The phenomenon is because the solution can better conduct electrical current as the concentration ions increases [26, 27]. The same illustration observed in Fig. 3(b), is supported in Table I and Table II, where increasing ion concentration results in higher solution conductivity. The water samples behaved very similarly when compared to the synthetic acid rain counterpart. However, all samples are converging to a conductivity range of $3.3-3.5 \mathrm{mS}$ during the final weeks of leaching.

\section{Settling and turbidity results}

The settling and turbidity tests were conducted with an aid of a polymer flocculant provided by the plant. The results depicted in Fig. 3 show the performance of the polymer as the $\mathrm{pH}$ is varied at constant flocculant dosage $30 \mathrm{ppm}$. It was observed in Fig. 4(a) that highest settling rate is a pH 7 and as the $\mathrm{pH}$ decreases, the performance of the polymer is affected and the settling rate decreases as well.
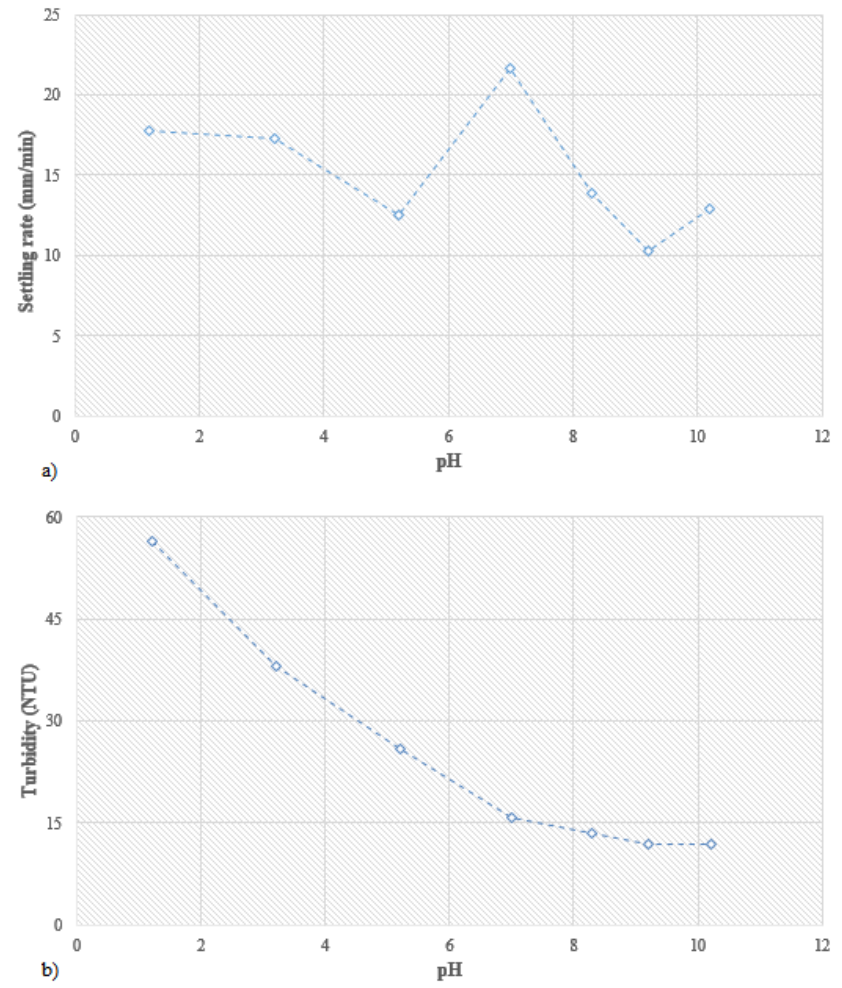

Fig. 4: The effect of a change in $\mathrm{pH}$ at a constant dosage of 30ppm. a) Settling rate. b) Turbidity

The same negative impact is observed in the turbidity results as well seen in Fig. 4(b). The turbidity increased from 15 NTU at $\mathrm{pH} 7$ to $58 \mathrm{NTU}$ at $\mathrm{pH} 1$. From these results, it is clear that a decrease in $\mathrm{pH}$ and increase in conductivity affect the operation of the thickener negatively. Considering Fig. 5, illustrated is the results that show how flocculant dosage affect settling rate and turbidity at constant $\mathrm{pH}$ of 3.8 , the $\mathrm{pH}$ similar to the $\mathrm{PW}$ sample. 

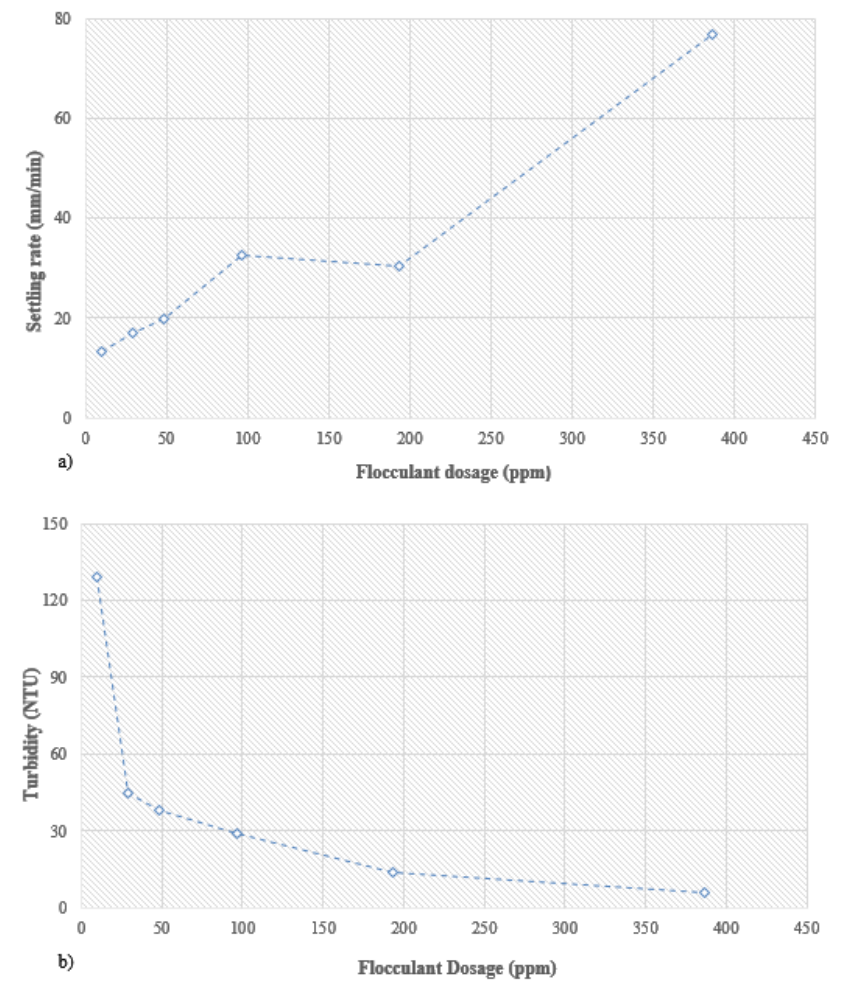

Fig. 5: The effect of a change in dosage at a constant $\mathrm{pH}$ 3.8. a) Settling rate. b) Turbidity

This experiment had an aim to quantify the extent at which what dosage at lower $\mathrm{pH}$ would be sufficient to give the same settling rate and turbidity that are similar to $\mathrm{pH} 7$ - similar to RW sample. From Fig. 5(a), it was observed that to achieve results similar to $\mathrm{pH} 7$ at $\mathrm{pH} 3.8$, the dosage increase from 30 $\mathrm{ppm}$ to $50 \mathrm{ppm}$ meaning the dosage required increase by a factor of 1.7. Thus the thickener operation will increase financial by the same factor. In Fig. 5(b), the turbidity results showed a much higher dosage of $100 \mathrm{ppm}$ is required to achieve a similar turbidity, this means the increase is by a factor of 3.3, double the factor needed to maintain the settling. This would mean that the thickener operation would cost 3 times to maintain at $\mathrm{pH} 3.8$ as it would in $\mathrm{pH}$ 7. Clearly showing the negative impact leaching imposes on thickener operation.

\section{E. Speciation results}

Heavy metal speciation properties for tailings samples treated with synthetic acid rain and for control samples treated with distilled water were investigated. Results were analyzed using PHREEQC workbench software. The software computes and presents the speciation of heavy metals pollutants in solution in terms of potential free hydrated ions and inorganic complexes. Illustration in Fig. 3(a), showed that the $\mathrm{pH}$ of leachate from both samples decreases with time and thus increases the potential trace heavy metals to dissolve into solution. Furthermore, the particle size distribution of the sediment depicted in Fig. 1, decreases the difficulty of the leaching of heavy metals because of the large surface area of the tailings particles
TABLE III: SPECIATION RESULTS FOR DOMINANT METALS WITHIN THE LEACHATE OF COAL TAILINGS

\begin{tabular}{|c|c|c|c|}
\hline Element & Species & $\%$ Range for SW Samples & $\%$ Range for DW Samples \\
\hline \multirow[t]{4}{*}{$\mathrm{Cd}$} & $\mathrm{Cd}^{+2}$ & $36.12-41.51$ & $38.30-43.35$ \\
\hline & $\mathrm{CdSO}_{4}$ & $40.33-41.23$ & $39.34-40.62$ \\
\hline & $\mathrm{Cd}\left(\mathrm{SO}_{4}\right)_{2}^{-2}$ & $15.78-18.23$ & $13.19-15.81$ \\
\hline & $\mathrm{CdCl}^{+}$ & $2.58-5.20$ & $2.82-5.43$ \\
\hline \multirow[t]{3}{*}{$\mathrm{Cl}$} & $\mathrm{Cl}$ & $99.95-99.96$ & $99.97-99.98$ \\
\hline & $\mathrm{MnCl}^{+}$ & $0.03-0.04$ & 0.02 \\
\hline & $\mathrm{ZnCl}^{+}$ & $0-0.01$ & $0-0.01$ \\
\hline \multirow[t]{2}{*}{$\operatorname{Co}(2)$} & $\mathrm{Co}^{+2}$ & $58.34-59.37$ & $58.56-60.18$ \\
\hline & $\mathrm{CoSO}_{4}$ & $40.54-41.88$ & $39.70-41.22$ \\
\hline \multirow[t]{2}{*}{$\operatorname{Co}(3)$} & $\mathrm{Co}^{+3}$ & $2.57-5.06$ & $2.94-5.97$ \\
\hline & $\mathrm{CoOH}^{+2}$ & $94.48-96.91$ & $93.46-96.41$ \\
\hline \multirow[t]{3}{*}{$\mathrm{Pb}$} & $\mathrm{Pb}^{+2}$ & $25.60-27.52$ & $26.95-29.46$ \\
\hline & $\mathrm{PbSO}_{4}$ & $61.58-62.02$ & $60.90-61.51$ \\
\hline & $\mathrm{Pb}\left(\mathrm{SO}_{4}\right)_{2}^{-2}$ & $9.88-11.92$ & $8.35-10.37$ \\
\hline \multirow[t]{2}{*}{$\operatorname{Mn}(2)$} & $\mathrm{Mn}^{+2}$ & $61.00-62.71$ & $61.60-63.38$ \\
\hline & $\mathrm{MnSO}_{4}$ & $37.23-38.94$ & $36.58-38.31$ \\
\hline $\operatorname{Mn}(3)$ & $\mathrm{Mn}^{+3}$ & 100 & 100 \\
\hline \multirow[t]{2}{*}{$\mathrm{Ni}$} & $\mathrm{Ni}^{+2}$ & $51.05-53.45$ & $52.30-54.97$ \\
\hline & $\mathrm{NiSO}_{4}$ & $46.42-48.72$ & $44.89-47.46$ \\
\hline \multirow[t]{3}{*}{$\mathrm{Zn}$} & $\mathrm{Zn}^{+2}$ & $42.61-45.84$ & $44.54-48.15$ \\
\hline & $\mathrm{ZnSO}_{4}$ & $44.27-44.44$ & $42.92-44.25$ \\
\hline & $\mathrm{Zn}\left(\mathrm{SO}_{4}\right)_{2}^{-2}$ & $10.64-12.84$ & $8.84-11.07$ \\
\hline \multirow[t]{2}{*}{$\mathrm{Fe}(2)$} & $\mathrm{Fe}^{+2}$ & $51.92-55.62$ & $55.38-55.75$ \\
\hline & $\mathrm{FeSO}_{4}$ & $46.55-47.73$ & $44.47-45.26$ \\
\hline \multirow[t]{5}{*}{$\mathrm{Fe}(3)$} & $\mathrm{Fe}^{+3}$ & $2.83-3.52$ & $2.46-3.57$ \\
\hline & $\mathrm{FeSO}_{4}^{+}$ & $47.93-66.24$ & $53.93-68.96$ \\
\hline & $\mathrm{Fe}\left(\mathrm{SO}_{4}\right)_{2}^{-}$ & $15.15-19.33$ & $8.72-24.01$ \\
\hline & $\mathrm{Fe}(\mathrm{OH})_{2}^{+}$ & $10.53-15.42$ & $12.70-14.41$ \\
\hline & $\mathrm{FeOH}^{+2}$ & $4.27-6.68$ & $4.28-6.82$ \\
\hline \multirow[t]{3}{*}{$S(6)$} & $\mathrm{SO}_{4}^{-2}$ & $92.00-94.66$ & $90.84-93.01$ \\
\hline & $\mathrm{HSO}_{4}^{-}$ & $3.04-5.59$ & $3.60-7.20$ \\
\hline & $\mathrm{MnSO}_{4}$ & $1.47-1.80$ & $1.23-1.39$ \\
\hline
\end{tabular}

exposed in solution. Thus, it is essential to quantify the extent of free hydrated ions formation, as an increase in the concentration of the free aqua metal ionic species, resulting in increased bioavailability of the ions. Thus, an increase in toxicity levels. The opposite is also valid, i.e. an increase in inorganic complexes, and a decrease in toxicity levels. The PHREEQC results are given in Table III. A total of 9 heavy metals are presented, and 7 of these heavy metals are classified as being major pollutants and 2 moderate pollutants. According to Huggins et.at, the 6 major pollutants are Cadmium) $(\mathrm{Cd})$, Chlorine $(\mathrm{Cl})$, Cobalt $(\mathrm{Co})$, Lead $(\mathrm{Pb})$, Manganese $(\mathrm{Mn})$, Nickel (Ni) and Zinc (Zn) [28, 29]. The moderate pollutants are Iron $(\mathrm{Fe})$ and Sulfur $(\mathrm{S})$. From Table III, it is shown that for both SW sample and DW, Cadmium up to $43.35 \%$ will be toxic as it exists as a free hydrated ion. Also, forming main to sulfate complexes, $40.33-41.23 \% \mathrm{CdSO}_{4}$ and to a lesser extent $2.58-5.20 \% \mathrm{Cd}\left(\mathrm{SO}_{4}\right)_{2}{ }^{-}$. Chlorine is predominantly found to be in the form of a free ion $\mathrm{Cl}^{-}$with the lowest concentration as high as $99.9 \%$. The analysis showed Cobalt has 2 main ions, $\mathrm{Co}^{+2}$ and $\mathrm{Co}^{+3}$, with the former having high toxicity, where up to $60 \%$ as free ion $\mathrm{Co}^{+2}$ and $40 \%$ will be 
inert as complex $\mathrm{CoSO}_{4}^{-}$, and the latter existing more as complex hydroxide $\mathrm{CoOH}^{+2}$ than a free ion. Lead is dominated by the sulfate complexes $\mathrm{PbSO}_{4}$ and $\mathrm{Pb}\left(\mathrm{SO}_{4}\right)_{2}{ }^{-2}$ with concentrations reaching 62.02 and $11.92 \%$ respectively. The free hydrated $\mathrm{Pb}^{+2}$ concentration is still significant as a concentration close to $30 \%$ for the DW sample. Manganese was mainly found to prefer the 2 free ion forms $\mathrm{Mn}^{+2}$ and $\mathrm{Mn}^{+3}$, where the latter did not form any organic complexes. The complex $\mathrm{MnSO} 4$ achieved concentrations over $38 \%$ as compared to the $63 \%$ reached by the free ion $\mathrm{Mn}^{+2}$. Nickel speciation was found to favour the formation of a free ion $\mathrm{Ni}^{+2}$ over the sulfate complex $\mathrm{NiSO}_{4}$, where they each reached concentrations of 54.97 and $48.72 \%$ respectively. The speciation of Zinc organic complexes, $\mathrm{ZnSO}_{4}$ and $\mathrm{Zn}\left(\mathrm{SO}_{4}\right)_{2}{ }^{-2}$ collectively outweighed the concentration of the free ion $\mathrm{Zn}^{+2}$. The free ion $\mathrm{Zn}^{+2}$ reached over $45 \%$ concentration. Iron has 2 free hydrated ion species that existed, $\mathrm{Fe}^{+2}$ and $\mathrm{Fe}^{+3}$. From the speciation results, it was observed over $51.92-55.75 \%$ of $\mathrm{Fe}^{+2}$ existed in ion form and $44.74-47.73 \%$ existed as a sulfate inorganic complex $\mathrm{FeSO}_{4}$. The $\mathrm{F}^{+3}$ was observed to not be as toxic as it was dominated by inorganic complexes. Sulfur speciation results showed that over $90 \%$ found to be the complex $\mathrm{SO}_{4}^{-2}$, this is supported by the change in $\mathrm{pH}$ illustrated in Fig. 3

\section{CONCLUSION}

In conclusion, it was observed that the PSD of the coal tailings had a maximum size of $250 \mu \mathrm{m}$, resulting in a high surface area that would promote the exposure of inherent minerals to the surrounding solution. It was also found that Pyrite and Iron Sulfate minerals were present in the coal tailings that were used for the study, and this would mean the oxidation of these minerals encourage AMD formation. The water samples taken from the plant showed signs of leaching of minerals and oxidation of acid-forming reagents, as it was observed that the drop in $\mathrm{pH}$ between the RW and PW samples and the increase in metal concentration. The phenomenon was also observed in the leaching column results, where a $\mathrm{pH}$ decrease and an increase in conductivity was observed. The impact on thickener operation was negative as it would mean the cost to maintain the same condition would increase by a factor of 1.7 for settling rate and 3.3 for the turbidity. The speciation results further showed the increase in metal concentration over time that is supported by the plant water samples. Furthermore, the speciation results showed that the impact of AMD formation increased toxicity to the environment as most of the species analyzed were dominated by free hydrated ion state, thus showing that the species would be bioavailable to pollute the environment.

\section{REFERENCES}

[1] Sabah, E. and Z.E. Erkan, Interaction mechanism of flocculants with coal waste slurry. Fuel, 2006. 85(3): p. 350-359. https://doi.org/10.1016/j.fuel.2005.06.005

[2] Slottee, S., J. Johnson, and M. Crozier, Paste thickening iron ore tailings update, in 2nd International Symposium on Iron Ore. 2008: Brazil.

[3] Patil, D.P., R. Honaker, and B.K. Parekh, Paste thickening of fine coal refuse. Coal Preparation, 2007. 27(4): p. 191-209. https://doi.org/10.1080/07349340701638848

[4] Edraki, M., et al., Designing mine tailings for better environmental, social and economic outcomes: a review of alternative approaches. Journal of Cleaner Production, 2014. 84: p. 411-420.

https://doi.org/10.1016/j.jclepro.2014.04.079

[5] Kumar, S., N.R. Mandre, and S. Bhattacharya, Flocculation Studies of Coal Tailings and the Development of a Settling Index. International Journal of Coal Preparation and Utilization, 2015. 36(6): p. 293-305. https://doi.org/10.1080/19392699.2015.1062001

[6] Fosso-Kankeu, E., et al., AMD formation and dispersion of inorganic pollutants along the mainstream in a mining area, in Mining Meets Water - Conflicts and Solutions, Drebenstedt, et al., Editors. 2016: Germany.

[7] Wagner, N.J. and B. Hlatshwayo, The occurrence of potentially hazardous trace elements in five Highveld coals, South Africa. International Journal of Coal Geology, 2005. 63(3-4): p. 228-246. https://doi.org/10.1016/j.coal.2005.02.014

[8] Fosso-Kankeu, E., et al., Geochemical Speciation of Metal Ions in the Leachate of Tailings Treated with Synthetic Rain Water, in Conference on Advances in Science, Engineering, Technology \& Waste Management. 2017: Parys, South Africa. p. 19-23.

[9] McCarthy, T.S., The impact of acid mine drainage in South Africa. South African Journal of Science, 2011. 107(5/6). https://doi.org/10.4102/sajs.v107i5/6.712

[10] Hairston, J.E., et al., Acid Rain: An Overview, in Alabama Cooperative Extension System. 2003: United States of America.

[11] Wentworth, C.K., A Scale of Grade and Class Terms for Clastic Sediments. The Journal of Geology, 1992. 30(5): p. 377-392. https://doi.org/10.1086/622910

[12] Jopony, M., G. Usup, and M. Mohamed, Particle Size Distribution of Copper Mine Tailings from Lohan Ranau Sabah and its Relationship with Heavy Metal Content. Pertanika, 1989. 10(1): p. 37-10.

[13] Pinetown, K.L., C.R. Ward, and W.A. van der Westhuizen, Quantitative evaluation of minerals in coal deposits in the Witbank and Highveld Coalfields, and the potential impact on acid mine drainage. International Journal of Coal Geology, 2007. 70(1-3): p. 166-183. https://doi.org/10.1016/j.coal.2006.02.013

[14] Fosso-Kankeu, E., A. Manyatshe, and F. Waanders, Mobility potential of metals in acid mine drainage occurring in the Highveld area of Mpumalanga Province in South Africa: Implication of sediments and efflorescent crusts. International Biodeterioration \& Biodegradation, 2017. 119: p. 661-670. https://doi.org/10.1016/j.ibiod.2016.09.018

[15] E. Fosso-Kankeu, A. Mulaba-Bafubiandi, B.B. Mamba, T.G. Barnard, Indigenous microorganism strains as bio-extractants of $\mathrm{Ca}, \mathrm{Fe}$ and $\mathrm{Mg}$ from metallurgical and mine drainages. The Southern African Institute of Mining and Metallurgy, Hydrometallurgy Conference 2009. Symposium Series S54, pp 93-100, 2009.

[16] E. Fosso-Kankeu, A. Mulaba-Bafubiandi, B.B. Mamba, T.G. Barnard, Assessing the effectiveness of a biological recovery of nickel from tailings dumps. Journal of Minerals Engineering. Vol. 24, pp. 470-472, 2011. https://doi.org/10.1016/j.mineng.2010.11.007

[17] E. Fosso-Kankeu, R. Kaitano, F. Waanders, A.F. Mulaba-Bafubiandi, Soil Quality in the Basin of Mine Effluents and the Potential of Alleviation of Metal Dispersion. An Interdisciplinary Response to Mine Water Challenges. International Mine Water Conference, August 2014 Xuzhou China. Editors, Sui, Sun \& Wang (Eds). 2014 China University of Mining andTechnology Press, Xuzhou, ISBN: 978-7-5646-2437-8. Pp374-378. 2014.

[18] E. Fosso-Kankeu, F. Waanders, A.F. Mulaba-Bafubiandi and S. Sidu, Leachability of suspended particles in mine water and risk of water contamination. $10^{\text {th }}$ ICARD/IMWA 2015; $10^{\text {th }}$ International Conference on Acid Rock Drainage \& IMWA Annual Conference. 21-24 April 2015 Santiago-Chile. Editors: Adrian Brown, Charles Bucknam, Joanna Burgess, Manuel Carballo, Devin Castendyk, Linda Figueroa, Lisa Kirk, Virginia McLemore, James McPhee, Mike O'Kane, Robert Seal, Jacques Wiertz, David Williams, Ward Wilson, Christian Wolkersdorfer. ISBN: 978-956-9393-28-0. Chap 4. Pp 1-9. 2015.

[19] E. Fosso-Kankeu, F.B. Waanders, and A.H. Munyai, Susceptibility of Metals Release from Tailings Dumps Located In the Krugersdorp Area. $7^{\text {th }}$ International Conference on Latest Trends in Engineering and Technology (ICLTET' 2015), November 12-27, 2015 Irene, Pretoria (South Africa). Editors: E. Muzenda and T Yingthawornsuk. ISBN: 978-93-84422-58-5. 2015. 
[20] A.H. Munyai, E. Fosso-Kankeu, F. Waanders, Biological influence on the mobility of metals from mine tailing dump located in Krugersdorp area. International Journal of Science and Research. ISSN: 2319-7064. Vol. 5, no. 4, pp. 1396-1403, 2016.

[21] A.H. Munyai, E. Fosso-Kankeu, F. Waanders, Mobility of metals from mine tailings using different types of organic acids: Batch leaching experiment. International Journal of Science and Research. Vol. 5, pp. 520-527, 2016.

[22] A.H. Munyai, E. Fosso-Kankeu, F. Waanders, Effects of organic acids on heavy metals released from mine tailings. International Conference on Advances in Science, Engineering, Technology and Natural Resources (ICASETNR-16) Nov. 24-25, 2016, Parys - South Africa. ISBN: 978-93-84468-79-8. 2016.

[23] E. Fosso-Kankeu, Investigation of the oxidation rate of sediments from AMD using humidity cell test. International Conference on Advances in Science, Engineering, Technology and Natural Resources (ICASETNR-16) Nov. 24-25, 2016, Parys - South Africa. ISBN: 978-93-84468-79-8. 2016.

[24] I.G. Erdogan, T. Moncho, E. Fosso-Kankeu, S.K.O. Ntwampe, F. Waanders, N. Hoth, A. Rand, B. Fourie, Hydrochemical Characteristics Of Open-Pit Groundwater From A Closed Metalliferous Mine In O'kiep, Namaqualand Region, South Africa. $9^{\text {th }}$ Int'l Conference on Advances in Science, Engineering, Technology \& Waste Management (ASETWM-17). 27-28 November 2017, Parys, South Africa. Editors: F. Waanders, E. Fosso-Kankeu, B. Topcuoglu, M. Plaisent, Y. Thaweesak. ISBN: 978-81-934174-6-1. Pp. 137-141. 2017.

[25] E. Fosso-Kankeu and J. Redelinghuys, Bacterial ecology of biofilms sustaining pollution by acid mine drainage near mining areas in Mpumalanga Province - South Africa. 11 ${ }^{\text {th }}$ ICARD/IMWA/MWD Conference "Risk to Opportunity". 10-14 September 2018 Pretoria, South Africa. C. Wolkersdorfer, L. Sartz, A. Weber, J. Burgess, G. Tremblay.ISBN: 978-0-620-80650-3 Vol 1 (2 volumes). 2018.

[26] Deschamps, T., et al., Laboratory study of surface paste disposal for sulfidic tailings: Physical model testing. Minerals Engineering, 2011. 24(8): p. 794-806. https://doi.org/10.1016/j.mineng.2011.02.013

[27] Deschamps, T., et al., Microstructural and geochemical evolution of paste tailings in surface disposal conditions. Minerals Engineering, 2008. 21(4): p. 341-353. https://doi.org/10.1016/j.mineng.2007.12.002

[28] E., H.F., Overview of analytical methods for inorganic constituents in coal. International Journal of Coal Geology, 2002. 50: p. 169-214. https://doi.org/10.1016/S0166-5162(02)00118-0

[29] C.A., B., et al., The determination of low-level trace elements in coals by laser ablation inductively coupled plasma-mass spectrometry. Fuel 1999. 78: p. $1665-1670$. 